Sains Peternakan Vol. 14 (2), September 2016: 30-41

ISSN 1693-8828

\title{
Produksi dan Kualitas Susu Sapi Perah Penderita Mastitis yang Mendapat Pengobatan Antibiotik
}

\author{
Riyanto, J., Sunarto, B.S. Hertanto, M. Cahyadi, Hidayah, R. dan W. Sejati \\ Program Studi Peternakan, Fakultas Pertanian, Universitas Sebelas Maret \\ Jl. Ir. Sutami 36 A, Kentingan, Surakarta \\ Email: jokoriyanto19@yahoo.com
}

\begin{abstract}
ABSTRAK
Penelitian ini bertujuan untuk mengetahui perbedaan produksi, kualitas fisik dan kualitas kimia susu sapi perah penderita mastitis sebelum dan sesudah diobati dengan antibiotik penicillin-streptomycin. Penelitian ini dilaksanakan di kelompok tani ternak (KTT) Subur Makmur, Desa Banyuanyar, Kecamatan Ampel, Kabupaten Boyolali. Materi yang digunakan adalah 15 ekor sapi perah Peranakan Friesian Holstein (PFH) yang menderita mastitis pada periode laktasi trimester ke-3, umur 3 sampai 5 tahun. Kombinasi antibiotik yang digunakan adalah penicillin $G$ serbuk injeksi 3 gram dicampur streptomycin sulfate serbuk injeksi 1 gram kemudian dilarutkan dengan aquadestilata hingga volume $15 \mathrm{ml}$. Pemberian antibiotik dilakukan 1 kali sehari selama 5 hari secara intramuscular dan intramammae. Penelitian ini dilakukan secara eksperimental dengan 2 perlakuan dan 15 ulangan. Data dianalisis dengan uji $t$-test sampel berpasangan (paired sample t-test). Hasil analisis menunjukkan perbedaan sangat nyata $(\mathrm{P}<0,01)$ terhadap produksi susu, kadar protein, laktosa, lemak, bahan kering tanpa lemak (BKTL) dan nilai Californian Mastitis Test $(\mathrm{CMT})$, perbedaan nyata $(\mathrm{P}<0,05)$ terhadap $\mathrm{pH}$, warna, bau dan kekentalan serta perbedaan tidak nyata $(\mathrm{P}>0,05)$ terhadap berat jenis. Kesimpulan dari penelitian ini adalah pengobatan menggunakan antibiotik penicillin-streptomycin pada sapi perah penderita mastitis efektif memperbaiki produksi, kualitas kimia dan kualitas fisik namun belum dapat memperbaiki berat jenis susu.
\end{abstract}

Kata kunci: mastitis, produksi, kualitas fisik, kualitas kimia, susu, penicllin, streptomycin

\section{Milk Quality and Production of Dairy Cow Mastitis Patients who Get Treatment of Antibiotics}

\begin{abstract}
This study aims to determine differences of production, the physical quality and chemical quality of dairy cattle mastitis patients before and after treatment with antibiotics penicillin-streptomycin. This research was conducted in farmer group (KTT) Subur Makmur, Banyuanyar Village, District Ampel, Boyolali. The material used is 15 cows PFH suffering from mastitis in lactation period 3rd trimester, aged 3 to 5 years. Combinations of antibiotics used is penicillin $G 3$ grams of mixed powder injection streptomycin sulfate injection of 1 gram powder is then dissolved with aquadestilata until volume of $15 \mathrm{ml}$. Antibiotics do 1 times a day for 5 days intramuscularly and intramammae. This research was carried out experimentally with two treatments and 15 replications. Data were analyzed by paired sample t-test (paired sample t-test). The analysis showed highly significant $(P<0,01)$ on milk production, protein content, lactose, fat, nonfat dry (BKTL) and the Californian Mastitis Test $(C M T)$, significant differences $(P<0,05) p H$, color, smell and consistency as well as the difference was not significant $(P>0,05)$ against density. The conclusion of this research is the treatment of penicillin-streptomycin antibiotic use in dairy cows mastitis patients effectively improve the production, chemical quality and physical qualities but can not improve the density of milk.
\end{abstract}

Keywords: mastitis, production, physical quality, chemical and bacteriological quality, milk, penicillin, streptomycin 


\section{PENDAHULUAN}

Susu merupakan salah satu produk peternakan yang dibutuhkan dalam jumlah banyak oleh masyarakat Indonesia. Kandungan gizi yang lengkap menjadi alasan tingginya kebutuhan dan permintaan masyarakat akan susu. Tingginya kebutuhan dan permintaan susu di Indonesia masih berbanding terbalik dengan rendahnya pemenuhan susu baik secara kuantitas maupun kualitas. Tingkat pemenuhan susu secara kuantitas masih sangat rendah terbukti dengan tingkat produksi dalam negeri pada tahun 2009 sebesar 827,2 ton/tahun dan memerlukan impor sebesar 173.305,30 ton/tahun (Direktorat Jenderal Peternakan dan Kesehatan Hewan, 2011). Kualitas susu dari peternak sapi perah lokal secara umum juga masih di bawah standar dimana hal tersebut berdampak pada rendahnya harga jual ditingkat koperasi maupun industri pengolahan susu (Utami et al., 2014; Usmiati dan Abubakar, 2009).

Salah satu penyebab rendahnya produksi dan kualitas susu sapi perah dari aspek kesehatan adalah adanya penyakit mastitis. Penyakit mastitis secara umum disebabkan oleh berbagai jenis bakteri antara lain Streptococcus agalactiae, S. disgalactiae, S. uberis, S. zooepidermicus, Staphylococcus aureus, Escherichia coli, Enterobacter aerogenes dan Pseudomonas aeruginosa serta Mycoplasma sp., Candida sp., Geotrichum sp. dan Nocardia sp. pada kasus mastitis mikotik (Akoso, 1996; Hastiono, 1984). Bakteribakteri tersebut akan menyebabkan kerusakan-kerusakan sel-sel alveoli pada ambing. Kerusakan yang terjadi tidak hanya mengakibatkan penurunan produksi susu namun juga kualitas susu. Penurunan kualitas susu merupakan kelainan pada susu karena bakteri mastitis merusak komposisi nutrien susu (Utami et al., 2014 dan Amran, 2013).

Berdasarkan gejala klinisnya, penyakit mastitis dapat diklasifikasikan ke dalam mastitis klinis dan subklinis. Mastitis klinis dapat dideteksi melalui kelainan kualitas fisik susu seperti bercampur dengan darah, mengental dan terlihat pecah. Mastitis klinis juga menampakkan gejala kebengkakan ambing, terasa panas jika disentuh, warnanya memerah, peningkatan suhu tubuh, penurunan nafsu makan dan ternak akan merasa kesakitan jika diperah. Mastitis subklinis memiliki ciri-ciri berbeda dengan mastitis klinis karena pada kasus ini tidak menampilkan kelainan fisik susu maupun ambing. Mastitis subklinis hanya dapat dideteksi dengan cara tes tertentu seperti uji Californian Matitis Test (CMT), uji kimia susu dan kultur bakteri (Sudhan dan Sharma, 2010; Suwito dan Indarjulianto, 2013). Kejadian kasus mastitis sampai akhir tahun 2006 adalah sekitar 75-83\% dengan prevalensi mastitis di Boyolali sebesar 62,5\% (Sudarwanto dan Sudarnika, 2008).

Penanganan dan pengobatan secara cepat perlu dilakukan terhadap penyakit mastitis setelah adanya gejala awal turunnya produksi dan kualitas susu. Metode penanggulangan yang efektif terhadap penyakit ini adalah dengan pemberian antibiotik. Salah satu antibiotik yang dapat 2 digunakan untuk mengobati penyakit mastitis adalah kombinasi antara penicillin dan streptomycin. Kombinasi penicillinstreptomycin merupakan salah satu kombinasi antibiotik yang memiliki tingkat efektivitas tinggi terhadap kasus mastitis. Menurut Owens et al. (2001), pengobatan menggunakan kombinasi antibiotik pencillinstreptomycin menunjukkan tingkat keberhasilan yang tinggi dalam menyembuhkan kasus mastitis pada ternak sapi perah. Penicillin merupakan antibiotik yang dapat membunuh bakteri gram positif (Rismardiati, 1985), sedangkan streptomycin efektif terhadap bakteri gram negatif penyebab mastitis (Suriyasathaporn, 2010). Berdasarkan fungsi kedua antibiotik tersebut, maka penyakit mastitis yang disebabkan oleh bakteri gram positif maupun negatif dapat disembuhkan secara optimal sehingga 
produksi dan kualitas susu meliputi warna, bau, kekentalan, nilai $\mathrm{pH}$, berat jenis, kadar protein, laktosa, lemak dan bahan kering tanpa lemak (BKTL) kembali normal serta tidak terjadi lagi infeksi mastitis pada masa laktasi selanjutnya.

Berdasarkan beberapa pemaparan diatas, maka perlu dilaksanakan penelitian untuk mengetahui efektifitas pengobatan dengan menggunakan antibiotik penicillinstreptomycin terhadap produksi dan kualitas fisik maupun kimia susu sapi perah penderita mastitis.

\section{MATERI DAN METODE}

\section{Waktu dan Tempat Pelaksanaan}

Penelitian ini dilaksanakan pada bulan Mei sampai November 2015 di kelompok tani ternak (KTT) Subur Makmur, Desa Banyuanyar, Kecamatan Ampel, Kabupaten Boyolali dan Laboratorium Balai Pelayanan dan Kesehatan Masyarakat Veteriner (Bapelkesmavet) Jawa Tengah di Boyolali.

\section{Materi Penelitian}

Materi yang digunakan adalah 15 ekor sapi perah $\mathrm{PFH}$ yang menderita mastitis pada periode laktasi trimester ke-3 dan umur 3 sampai 5 tahun. Bahan penyusun kombinasi antibiotik yang digunakan adalah penicillin $G$ dan streptomycin sulfate serbuk injeksi serta aquadestilata sebagai pelarut. Alat yang digunakan untuk mendeteksi mastitis adalah Californian Mastitis Test (CMT).

\section{Metode Penelitian}

Pada tahap persiapan penelitian
dilakukan kegiatan pra-survei meliputi observasi langsung ke kandang-kandang para peternak dan melakukan tanya jawab kepada pemilik sapi perah mengenai status reproduksi, produksi susu dan kesehatan ternak (Supar dan Ariyanti, 2008). Pemilihan lokasi dan sapi perah sebagai objek penelitian menggunakan metode purposive sampling dengan kriteria tertentu sesuai tujuan penelitian (Teddli and $\mathrm{Yu}, 2007$ ). Lokasi Kecamatan Ampel dipilih sebagai tempat penelitian karena di daerah sapi perah benyak dipelihara oleh masyarakat setempat (Utomo dan Miranti, 2010). Kabupaten Boyolali juga merupakan daerah sentra produksi susu sapi perah di Jawa Tengah. Penentuan sapi yang menderita mastitis dilakukan dengan metode uji CMT. Uji CMT akan memberikan informasi sapi yang terserang mastitis melalui penggumpalan susu (Adriani, 2010).

Sapi-sapi yang terbukti terserang penyakit mastitis kemudian diberi perlakuan dengan pemberian antibiotik penicillinstreptomycin secara injeksi intramuscular dan intramammae sehari 1 kali selama 5 hari. Pengobatan dilakukan pada sore hari dengan tujuan supaya antibiotik mempunyai waktu yang lebih lama untuk bereaksi sebelum dilakukan pemerahan. Kombinasi antibiotik terdiri dari 3 gram penicillin $G$ dicampur 1 gram streptomycin sulfate kemudian dilarutkan menggunakan aquadestilata hingga volum larutan mencapai $15 \mathrm{ml}$. Dosis yang digunakan dalam pengobatan sapi mastitis adalah $10 \mathrm{ml}$ secara intramuscular dan 1,25 $\mathrm{ml}$ per puting atau secara intramammae (Direktorat Jenderal Peternakan, 2007). Selama proses penelitian, pemberian bahan pakan dilakukan sesuai dengan kegiatan pemeliharaan oleh para peternak. Bahan pakan yang diberikan antara lain rumput gajah, rumput kalanjana, rumput lapang dan ampas tahu.

Penghitungan produksi dan pengujian kualitas susu dilakukan sebelum dan sesudah pengobatan. Peubah penelitian berupa produksi susu, warna, bau, kekentalan, nilai $\mathrm{pH}$, berat jenis, kadar protein, laktosa, lemak dan BKTL.

\section{Desain Penelitian}

Penelitian ini dilakukan secara eksperimental dengan 2 perlakuan dan 15 ulangan. Perlakuannya adalah P1 = sebelum 
diobati dengan antibiotik penicillinstreptomycin $; \mathrm{P} 2$ = sesudah diobati dengan antibiotik penicillin-streptomycin.

\section{Analisis Data}

Data yang diperoleh kemudian dianalisis menggunakan metode uji $t$-test sampel berpasangan (paired sample t-test) dengan bantuan program software SPSS 16 (Statistic Product and Service Solution).

\section{HASIL DAN PEMBAHASAN}

\section{Kondisi Umum Lokasi Penelitian}

KTT Subur Makmur berada di daerah lahan kering dataran tinggi. Hasil survei awal menunjukkan bahwa ternak sapi perah berkembang dengan baik di daerah ini. Banyaknya sapi perah yang dipelihara di daerah ini belum diimbangi dengan manajemen pemeliharaan yang baik. Para peternak secara umum masih menggunakan sistem pemeliharaan tradisional tanpa memperhatikan pentingnya menjaga kebersihan lingkungan kandang ternak sapi perah. Kondisi lingkungan yang buruk menyebabkan bakteri mudah berkembang biak dan rentan masuk ke lubang puting sapi perah. Bakteri yang terakumulasi di ambing inilah yang menyebabkan mastitis.

Pengamatan mengenai peningkatan produksi susu, perubahan kualitas fisik maupun kimia susu sebelum dan sesudah pengobatan menjadi indikator yang perlu diperhatikan karena dapat memberikan informasi keberhasilan pengobatan terhadap sapi perah penderita mastitis. Hasil analisis paired sample t-test dari perbandingan ratarata produksi dan nilai kualitas fisik susu sebelum dan sesudah pengobatan dapat dilihat pada Tabel 1.

Tabel 1. Produksi dan Kualitas Susu Sapi Perah Mastitis Sebelum dan Sesudah Diobati

\begin{tabular}{lllll}
\hline Peubah & N & Mean P1 & Mean P2 & Nilai P \\
\hline Produksi susu (liter) & 15 & $9,310 \pm 5,332 \mathrm{a}$ & $10,187 \pm 5,117 \mathrm{~b}$ & 0,001 \\
Nilai pH & 15 & $6,679 \pm 0,103 \mathrm{a}$ & $6,596 \pm 0,117 \mathrm{~b}$ & 0,020 \\
Berat jenis (gr/ml) & 15 & $1,026 \pm 0,002$ & $1,027 \pm 0,002$ & 0,299 \\
Warna & 15 & $2,200 \pm 0,941 \mathrm{a}$ & $2,800 \pm 0,561 \mathrm{~b}$ & 0,023 \\
Bau & 15 & $2,267 \pm 0,961 \mathrm{a}$ & $2,867 \pm 0,516 \mathrm{~b}$ & 0,023 \\
Kekentalan & 15 & $2,200 \pm 0,862 \mathrm{a}$ & $2,667 \pm 0,724 \mathrm{~b}$ & 0,029 \\
Kadar Protein (\%) & 15 & $2,750 \pm 0,190 \mathrm{a}$ & $2,890 \pm 0,190 \mathrm{~b}$ & 0,001 \\
Kadar Laktosa (\%) & 15 & $4,100 \pm 0,280 \mathrm{a}$ & $4,340 \pm 0,280 \mathrm{~b}$ & 0,001 \\
Kadar Lemak (\%) & 15 & $3,540 \pm 1,000 \mathrm{a}$ & $4,870 \pm 1,120 \mathrm{~b}$ & 0,001 \\
Kadar BKTL (\%) & 15 & $7,290 \pm 0,750 \mathrm{a}$ & $7,840 \pm 0,450 \mathrm{~b}$ & 0,006 \\
Nilai CMT & 15 & $2,083 \pm 1,263 \mathrm{a}$ & $0,550 \pm 0,502 \mathrm{~b}$ & 0,001 \\
\hline
\end{tabular}

Keterangan: CMT = Californian Mastitis Test, $\mathrm{N}=$ Jumlah sampel, $\mathrm{P} 1=$ Sebelum diobati dengan penicillinstreptomycin, $\mathrm{P} 2=$ Sesudah diobati dengan penicillin-streptomycin,${ }^{\mathrm{a}-\mathrm{b}}$ Superskrip yang berbeda pada baris yang sama menunjukkan perbedaan.

\section{Produksi susu}

Perbandingan hasil rata-rata produksi susu sapi perah sebelum dan sesudah pengobatan antibiotik penicillin-streptomycin menunjukkan perbedaan yang sangat nyata $(\mathrm{P}<0,01)$. Rata-rata produksi susu sapi perah peternak sebelum dan sesudah diobati dengan 
antibiotik penicillin-streptomycin adalah 9,31 dan 10,19 liter/ekor/hari (Tabel 1). Hasil tersebut menunjukkan bahwa perlakuan pengobatan memberikan pengaruh yang baik karena rata-rata produksi susu mengalami peningkatan setelah diobati dengan penicillinstreptomycin. Menurut Rismardiati (1985) antibiotik penicillin-streptomycin bekerja dengan menghasilkan efek bakterisida pada bakteri yang sedang aktif membelah sehingga aktivitas bakteri dapat terganggu bahkan mati. Berkurangnya bakteri akan menyebabkan perbaikan sel epitel pada alveoli kelenjar susu serta kuartir ambing membaik sehingga produksi susu menjadi normal kembali.

Hasil yang didapat diperkuat oleh penelitian yang dilakukan oleh Poutrel and Ducelliez (1978) bahwa penggunaan antibiotik penicillin-streptomycin dapat menyembuhkan 23 kuartir dari 46 kuartir ambing sapi perah yang menderita mastitis. Kesembuhan kuartir pada sapi perah yang mengalami mastitis otomatis akan meningkatkan jumlah produksi susu yang dihasilkan.

\section{Kualitas Fisik Susu}

Hasil analisis nilai $\mathrm{pH}$ sebelum dan sesudah diobati menunjukkan perbedaan yang nyata $(\mathrm{P}<0,05)$ (Tabel 1). Rata-rata nilai $\mathrm{pH}$ susu setelah diobati mengalami penurunan yang berarti pengobatan antibiotik penicillinstreptomycin memberikan perbaikan terhadap nilai $\mathrm{pH}$ susu menuju ke standar normal. Nilai pH susu segar normal yaitu berkisar antara 6,3 sampai 6,8 (Standar Nasional Indonesia, 2011). Menurut pendapat Herendra (2009), nilai $\mathrm{pH}$ susu lebih dari 6,7 biasanya dihasilkan oleh ternak menderita penyakit, terutama radang ambing (mastitis). Menurut Sudarwanto dan Sudarnika (2008), nilai $\mathrm{pH}$ susu mastitis subklinik berkisar antara 6,3 dan 7,2 (tes IPB-1). Penelitian tersebut juga menunjukkan adanya hubungan antara kenaikan nilai $\mathrm{pH}$ susu yang berbanding lurus dengan kenaikan derajat mastitis. Perubahan yang terjadi berhubungan dengan peningkatan permeabilitas pada bahan sel epithel mammary yang mengakibatkan perpindahan komponen darah ke susu meliputi sitrat dan bikarbonat sehingga terjadi abnormalitas nilai pH. Tingkat keberhasilan sembuhnya sapi perah yang sebelumnya terinfeksi mastitis juga diperkuat oleh pendapat Hassan (2013) yang menjelaskan bahwa perbedaan nilai $\mathrm{pH}$ pada ternak mastitis terbukti signifikan jika dibandingkan dengan $\mathrm{pH}$ ternak yang tidak terinfeksi mastitis.

Perbandingan rata-rata berat jenis susu sebelum maupun sesudah diobati menunjukkan perbedaan yang tidak nyata (P>0,05) (Tabel 1). Menurut Sudarman dan Diapari (2012), pengobatan pada mastitis subklinis tidak memengaruhi nilai berat jenis susu. Hal tersebut juga diperkuat oleh penelitian Primadani et al. (2013) bahwa pencegahan dan penanganan terhadap pertumbuhan bakteri pada sapi perah tidak berpengaruh terhadap nilai berat jenis susu. Berat jenis susu lebih banyak dipengaruhi oleh kandungan karbohidrat pada pakan ternak (Sudarman dan Diapari, 2012). Data rata-rata nilai berat jenis susu mastitis sesudah diobati menunjukkan kecenderungan perbaikan yaitu terjadi peningkatan dari 1,026 menjadi 1,027. Peningkatan nilai berat jenis sesudah diobati berada di angka normal sesuai Standar Nasional Indonesia (2011) yaitu minimal 1,027. Penelitian yang dilakukan oleh Amran (2013) menunjukkan rata-rata berat jenis susu pada peternakan sapi perah rakyat dengan berbagai jenis pakan adalah 1,0276 .

Penilaian warna pada susu dari sapi perah penderita mastitis yang telah diobati menunjukkan perbedaaan nyata $(\mathrm{P}<0,05)$ dibandingkan dengan sebelum diobati menggunakan antibiotik penicillinstreptomycin (Tabel 1). Sampel susu sebelum diobati menunjukkan abnormalitas warna yang diantaranya menampilkan susu dengan warna putih kemerahan dan putih pucat. Hasil tersebut sesuai dengan pendapat Sharif et al. 
(2009) dan Rismardiati (1985) yang berpendapat bahwa indikasi sapi perah terinfeksi mastitis dapat dilihat dari tandatanda warna susu menjadi putih kemerahan atau putih pucat. Menurut Akoso (1996), penyakit mastitis klinis akan menampilkan penyimpangan kualitas warna susu menjadi kemerahan karena adanya darah atau bercampur dengan nanah. Hasil penelitian menunjukkan bahwa pengobatan antibiotik penicillin-streptomycin mampu memperbaiki penampilan warna susu yaitu semula menampakkan warna yang menyimpang menjadi normal putih kekuningan setelah diobati. Perbaikan warna yang terjadi sesuai dengan pendapat Usmiati dan Abubakar (2009) bahwa warna susu normal adalah putih kekuningan. Warna putih normal pada susu disebabkan oleh penyebaran butiran-butiran koloid lemak sedangkan bahan utama yang memberi warna kekuning-kuningan adalah karoten dan riboflavin (Maitimu et al., 2012).

Hasil analisis nilai bau susu setelah pengobatan dengan antibiotik penicillinstreptomycin pada sapi perah penderita mastitis menunjukkan perbedaan yang nyata $(\mathrm{P}<0,05)$ (Tabel 1). Beberapa sampel susu penelitian yang terindikasi memiliki bau menyimpang seperti bau amis atau tidak berbau mengalami perubahan kearah normal manjadi bau khas susu setelah sapi perah diobati. Hal ini membuktikan bahwa pengobatan menggunakan antibiotik penicillin-streptomycin dapat memperbaiki rata-rata skor bau pada sampel susu dari sapi perah. Menurut Standar Nasional Indonesia (2011), susu normal memiliki bau yang tidak berubah ataupun menyimpang yaitu bau khas susu. Bau khas susu disebabkan karena kandungan laktosa susu yang tinggi dan kandungan khorida yang relatif rendah (Maitimu et al., 2012). Menurut Kusmanto dan Hidayati (2011), bahan pangan akan berubah dari aroma normal apabila kandungan bakterinya melebihi batas maksimum yaitu lebih dari 1x106 CFU/ml pada susu berdasarkan Standar Nasional Indonesia
(2011). Salah satu penyebab terjadinya penyimpangan bau pada susu adalah adanya dekomposisi komponen susu (laktosa) serta peningkatan khlorida akibat pertumbuhan dan perkembangbiakan bakteri. Hal tersebut sesuai dengan pendapat Schroeder (2012) bahwa peningkatan jumlah sel somatik dan bakteri pada susu mengakibatkan penurunan laktosa dan peningkatan khlorida. Pengobatan antibiotik penicillin-streptomycin pada sapi perah mastitis terbukti memperbaiki tampilan bau susu sehingga mengindikasikan keberhasilan pengobatan yang dilakukan. Perbaikan nilai bau susu terjadi karena adanya penurunan jumlah sel somatik dan bakteri sehingga kandungan laktosa dan khlorida secara bertahap kembali normal.

Hasil penilaian kekentalan susu yang didapat dari pengobatan sapi perah penderita mastitis menunjukkan perbedaan yang nyata $(\mathrm{P}<0,05)$. Berdasarkan Tabel 1., rataan skor dari kekentalan susu mengalami kenaikan yang artinya terjadi perbaikan penampilan kekentalan susu. Hal ini menunjukkan bahwa pengobatan dengan antibiotik penicillinstreptomycin mampu memperbaiki kekentalan susu pada sapi perah penderita mastitis. Menurut Standar Nasional Indonesia (2011), susu normal memiliki konsistensi yang normal yaitu tidak telalu kental dan encer. Gustiani (2009) juga menjelaskan bahwa terdapat beberapa kerusakan fisik pada susu yang disebabkan oleh cemaran mikroorganisme. Kerusakan tersebut antara lain pengasaman yang disertai penggumpalan akibat dari fermentasi laktosa menjadi asam laktat sehingga $\mathrm{pH}$ susu menurun dan kasein menggumpal, susu berlendir seperti tali karena terjadinya pengentalan dan pembentukan lendir akibat pengeluaran bahan seperti kapsul dan bergetah oleh beberapa jenis bakteri dan penggumpalan susu tanpa penurunan $\mathrm{pH}$ yang disebabkan oleh bakteri (Akoso, 1996). Sapi yang terinfeksi mastitis juga terkadang menghasilkan susu menjadi pecah sehingga terlihat lebih encer (Direktorat Jenderal Peternakan dan Kesehatan Hewan, 
2014). Sharif et al. (2009) juga menyatakan bahwa ciri-ciri yang mengindikasikan susu terinfeksi mastitis adalah susu terlalu encer. Hal ini disebabkan oleh kegiatan enzim atau penambahan asam sehingga terjadi peningkatan reaksi antar protein penyusun susu dengan asam tersebut. Penjelasan diatas menunjukkan bahwa pengobatan dengan antibiotik penicillin-streptomycin dapat memperbaiki penampilan kekentalan susu yang dihasilkan dari sapi penderita mastitis.

\section{Kualitas Kimia Susu}

Perbandingan rata-rata kadar protein susu sapi perah sebelum dan sesudah pengobatan antibiotik penicillin-streptomycin menunjukkan hasil yang sangat signifikan $(\mathrm{P}<0,01)$. Sampel susu dari sapi $\mathrm{PFH}$ penderita mastitis memiliki rata-rata kadar protein yang rendah. Hal ini disebabkan terjadi peradangan pada kelenjar susu akibat pertumbuhan bakteri (Taylor, 2006). Sesudah diobati kadar protein susu sapi PFH mengalami peningkatan yaitu $0,14 \%$. Kadar protein setelah pengobatan tergolong normal. Hal ini sesuai dengan Standar Nasional Indonesia (2011) bahwa kadar protein minimal 2,80\%. Pemberian antibiotik penicillin-streptomycin pada sapi $\mathrm{PFH}$ mastitis dapat memperbaiki sel sekretori ambing. Menurut Rismardiati (1985), penicillin akan membunuh bakteri yang mengganggu kinerja enzim dalam pembentukan kasein sehingga kadar protein susu sapi PFH penderita mastitis meningkat. Pendapat ini diperkuat oleh penelitian Ikiz et al. (2013), bahwa antibiotik penicillinstreptomycin memiliki tingkat sensitivitas tinggi terhadap bakteri Staphylococcus aureus yaitu mencapai $75,00 \%$ dan $16,66 \%$. Bakteri tersebut merupakan agen utama penyebab mastitis dengan prevalensi sebesar 52,50\% (Abdelrady dan Sayed, 2009).

Hasil pengobatan dengan penicillinstreptomycin menunjukkan bahwa terjadi peningkatan yang sangat signifikan terhadap kadar laktosa susu sapi PFH mastitis $(\mathrm{P}<0,01)$. Susu sapi PFH penderita mastitis memiliki kadar laktosa rendah karena proses sintesa laktosa susu yang terhambat (Kitchen, 1981). Hal ini disebabkan oleh kerusakan sel sekretoris dan terjadi peningkatan jumlah sel somatis (Harmon, 1994). Sesudah diobati dengan penicillin-streptomycin rata-rata kadar laktosa susu sapi PFH penderita mastitis mengalami peningkatan $0,24 \%$. Kadar laktosa hasil pengujian masih tergolong rendah karena kadar laktosa susu sapi minimal 4,50\% (Eckles et al., 1980). Hal ini disebabkan oleh kondisi sapi pada periode laktasi trimester ketiga. Menurut Sevia et al. (1999), kadar laktosa susu sapi PFH penderita mastitis subklinis akan menurun seiring dengan bertambahnya bulan laktasi. Pengobatan dengan antibiotik penicillin-streptomycin menghasilkan efek bakterisid pada mikrobia yang sedang aktif dalam membelah sehingga aktivitas bakteri dapat terganggu dan terjadi penurunan jumlah sel somatis. Berkurangnya bakteri akan menyebabkan perbaikan sel pada kelenjar susu sehingga kadar laktosa mengalami perbaikan.

Pengobatan mastitis dengan penicillinstreptomycin sangat signifikan dalam meningkatkan kadar lemak susu sapi PFH mastitis $(P<0,01)$. Rata-rata kadar lemak susu sapi PFH mastitis sesudah diobati meningkat $1,33 \%$. Kadar lemak susu sapi minimal 3,00\% (Standar Nasional Indonesia, 2011) sehingga kadar lemak susu setelah diobati ini tergolong cukup tinggi yaitu 4,87\%. Hal ini disebabkan oleh kondisi sapi yang digunakan untuk penelitian pada periode laktasi trimester ketiga. Menurut Gurmessa dan Achenef (2012), bulan laktasi berpengaruh terhadap kadar lemak susu, semakin bertambahnya bulan laktasi maka kadar lemak susu akan semakin meningkat. Pernyataan tersebut diperkuat oleh Basya (1983) bahwa terjadi peningkatan kadar lemak susu 0,50-1,50\% pada trimester akhir dibanding dengan laktasi awal. Kadar lemak susu sapi PFH penderita mastitis mengalami penurunan karena jumlah 
sel somatis yang mengalami ruptur mencapai $5.000 .000 \mathrm{sel} / \mathrm{ml}$. Sel somatis sebesar $22,00 \%$ terdiri dari sel epitel sekretori ambing yang dalam keadaan normal jumlah sel somatis kurang dari $100.000 \mathrm{sel} / \mathrm{ml}$ (Lee et al., 1980; National Mastitis Council, 2001). Sel epitel sekretori merupakan sel yang berfungsi sebagai tempat biosintesa lemak susu sehingga semakin tinggi jumlah sel somatis yang mengalami ruptur maka penurunan terhadap kadar lemak susu akan semakin tinggi. Pengobatan dengan antibiotik penicillin-streptomycin mampu menghambat pertumbuhan dan perkembangan bakteri sehingga dapat menurunkan jumlah sel somatis dan memberikan efek positif terhadap kadar lemak susu (Suwandi, 2003; Sudarwanto et al., 2006).

Pengobatan antibiotik penicillinstreptomycin sangat signifikan dalam meningkatkan kadar BKTL susu sapi PFH mastitis $(\mathrm{P}<0,01)$. Menurut Soedono et al. (2003) protein dan laktosa merupakan komponen terbesar BKTL. Pernyataan ini diperkuat oleh Huda (2007) bahwa perubahan kadar BKTL susu sebagian besar diakibatkan dari adanya perubahan kandungan protein susu. Pada penelitian ini kadar protein dan laktosa susu cukup rendah sehingga kadar BKTL juga rendah. Menurut Rismardiati (1985) melalui pemberian antibiotik penicillin-streptomycin dapat memperbaiki sel sekretori ambing sehingga kadar protein dan kadar laktosa lebih tinggi yang berdampak pada perbaikan kadar BKTL susu sapi PFH. Sesudah diobati dengan penicillinstreptomycin, rata-rata kadar BKTL susu sapi PFH penderita mastitis mengalami peningkatan $0,55 \%$. Kadar BKTL tergolong normal dan memenuhi standar minimal 7,80\% (Standar Nasional Indonesia, 2011). Hasil penelitian Poeloengan (2009) menunjukkan bahwa daya antibakteri antibiotika golongan penicillin lebih besar dibandingkan konsentrasi 50,00\% ekstrak etanol daun encok yang memberikan zona hambat yang lebih besar sehingga terbukti lebih efektif jika sapi perah mastitis diobati dengan penicillinstreptomycin, sedangkan pemberian temu putih untuk pengobatan sapi perah tidak berpengaruh terhadap kadar BKTL susu karena belum mampu menurunkan jumlah bakteri penyebab mastitis (Susanty dan Nurdin, 2012).

\section{Nilai CMT}

Perbandingan hasil rata-rata nilai CMT susu sapi perah sebelum dan setelah pengobatan antibiotik penicillin-streptomycin menunjukkan perbedaan yang sangat nyata $(\mathrm{P}<0,01)$ (Tabel 1). Penurunan rata-rata nilai CMT didapat dari 38 puting yang terserang mastitis mengalami penurunan skor CMT bahkan 13 diantaranya sembuh total setelah pengobatan. Hasil tersebut membuktikan bahwa pengobatan menggunakan kombinasi antiobiotik penicillin-streptomycin dapat menurunkan bahkan menyembuhkan sapi perah yang terinfeksi mastitis. Menurut Poutrel dan Ducelliez (1978) nilai CMT berhubungan dengan total jumlah bakteri pada susu, sehingga dengan penurunan nilai CMT maka tingkat infeksi bakteri penyebab mastitis juga mengalami penurunan. Reaksi reagen CMT sensitif terhadap susu yang terinfeksi Staphylococcus aureus, Streptococcus sp., E. Coli dan bakteri lain penyebab mastitis (Reugg and Reinemann, 2002).

Menurut Fajrin et al. (2013) dalam penelitiannya menunjukkan terjadi hubungan negatif antara tingkat mastitis dengan produksi dan kualitas susu yang berarti semakin tinggi nilai skor CMT maka semakin rendah produksi dan kualitas susu pada sapi perah. Adriani (2010) menjelaskan bahwa mekanisme kerja reagen arylsulfonate pada uji CMT akan memecah inti sel somatik yang terdapat pada susu sehingga mengakibatkan penggumpalan. Hal tersebut sejalan dengan pendapat Nurdin (2007) bahwa derajat mastitis yang ditampilkan pada uji CMT menunjukkan jumlah sel somatik yang terdapat pada susu yaitu semakin banyak 
CMT. Berdasarkan penjelasan di atas menunjukkan bahwa pengobatan antibiotik penicillin-streptomycin dapat menurunkan jumlah sel somatik sehingga derajat mastitis pada sapi perah juga mengalami penurunan.

\section{SIMPULAN}

Pengobatan dengan antibiotik penicillin-streptomycin efektif memperbaiki jumlah produksi susu, kualitas kimia dan kualitas fisik susu namun belum dapat memperbaiki berat jenis susu sapi perah penderita mastitis.

\section{DAFTAR PUSTAKA}

Abdelrady, A. and M. Sayed. 2009. Epidemiological Studies On Subclinical Mastitis In Dairy Cows In Assiut Governorate. Veteriner World. pp. 373-380.

Adriani. 2010. Penggunaan somatik cell count (SCC), jumlah bakteri dan california mastitis test (CMT) untuk deteksi mastitis pada kambing. Jurnal Ilmiah Ilmu-Ilmu Peternakan. 13(5): 229-234.

Akoso, B.T. 1996. Kesehatan Sapi. Penerbit Kanisius. Yogyakarta.

Amran, M.U. 2013. Produksi dan Karakteristik Fisik Susu Sapi Perah Dengan Pemanfaatan Bahan Baku Lokal berupa Umbi Ubi Jalar (Ipomoea batalas) sebagai Pakan Alternatif. Skripsi. Jurusan Produksi Ternak. Fakultas Peternakan. Universitas Hasanuddin. Makassar.

Basya, S. 1983. Berbagai faktor yang mempengaruhi kadar lemak susu sapi perah. Wartazoa. 1(2): 13-15.

Direktorat Jenderal Peternakan dan Kesehatan Hewan. 2011. Rencana Strategis Direktorat Jenderal Peternakan dan Kesehatan Hewan Tahun 2010-2014. Kementerian Pertanian. Republik Indonesia.
Direktorat Jenderal Peternakan dan Kesehatan Hewan. 2014. Manual Penyakit Hewan Mamalia Cetakan ke-2. Kementerian Pertanian. Republik Indonesia.

Direktorat Jenderal Peternakan. 2007. Indeks Obat Hewan Indonesia Edisi VI. Departemen Pertanian. Republik Indonesia.

Eckles, C.H., W.R. Combs and H. Macy. 1980. Milk and Milk Product. Mc.Graw-Hill Book Co. New York.

Fajrin, F., Sarwiyono dan P. Surjowardojo. 2013. Hubungan level mastitis terhadap produksi dan kualitas susu pada sapi perah. Jurnal Universitas Brawijaya.

Malang. http://jurnal.ub.ac.id. (Diakses pada tanggal 18 Januari 2016).

Gurmessa, J. and M. Achenef. 2012. Effect of lactation stage, pregnancy, parity and age on yield and major components of raw milk in bred cross Friesian Holstein cows. World Journal of Dairy and Food Sciences. 7(2): 146-149.

Gustiani, E. 2009. Pengendalian cemaran mikrobia pada bahan pangan asal ternak (daging dan susu) mulai dari peternakan sampai dihidangkan. Jurnal Penelitian dan Pengembangan Peternakan. 28(3): 96-100.

Harmon, R.J. 1994. Physiology of mastitis and factors affecting somatic cell counts. Journal of Dairy Science. 77(7): 2103-2112.

Hassan, H.J. 2013. Variations in milk composition of some farm animals resulted by sub-clinical mastitis in AlDiwania Province. Bas. Journal Veterinary Result. 12(2): 17-24.

Hastiono, S. 1984. Mastitis mikotik, radang kelenjar susu oleh cendawan pada ternak perah. Wartazoa. 1(4): 9-12.

Herendra, M.H.P. 2009. Pengaruh Proses Distribusi terhadap Peningkatan Angka Kuman pada Susu Sapi Segar di Peternakan Ram Kecamatan Mojosongo Kabupaten Boyolali. 
Skripsi. Fakultas Kedokteran. Universitas Sebelas Maret. Surakarta.

Huda, M.K. 2007. Tampilan SNF dan Berat Jenis Susu Sapi PFH yang Diberi Ransum dengan Tingkat Konsumsi Berbeda. Skripsi. Fakultas Peternakan. Universitas Brawijaya.

Ikiz, S., B. Basaran, E.B. Bingol, O. Cetin, G. Kasikci, N.Y. Ozgur, M. Ucmak, O. Yilmaz, M.C. Gunduz dan A. Sabuncu. 2013. Presence and antibiotic susceptibility patterns of contagious mastitis agents (Staphylococcus aureus and Streptococcus agalactiae) isolated from milks of dairy cows with subclinical mastitis. Turkish of Journal Veterinary and Animal Sciences. 37(5): 569-574.

Kitchen, B.J. 1981. Bovine mastitis milk compositional changes and related diagnostic tests. Journal of Dairy Science. 48(1): 167-188.

Kusmanto dan A.M. Hidayati. 2011. Total bakteri dan sifat organoleptik minuman sari tempe dengan variasi waktu penyimpanan. Jurnal Pangan dan Gizi. 2(3): 75-87.

Lee, C.S., F.B.P. Wooding and P. Kemp. 1980. Identification properties, and differential counts of cell populations using electron microscopy of dry cows secretions, colostrum and milk from normal cows. Journal of Dairy Research. 47(1): 39-50.

Maitimu, C.V., A.M. Legowo dan A.N. AlBaarri. 2013. Karakteristik mikrobiologis, kimia, fisik dan organoleptik susu pasteurisasi dengan penambahan ekstrak daun Aileru (Wrightia calycina) selama penyimpanan. Jurnal Aplikasi Teknologi Pangan. 2(1): 18-29.

National Mastitis Council. 2001. Guidelines on normal and abnormal raw milk based on somatic cell counts and signs of clinical mastitis. Bulletin
International Dairy Federation 321. pp. 39.

Nurdin, E. 2007. Pengaruh pemberian tongkol bunga matahari (Helianthus annuus 1.) dan probiotik terhadap penurunan derajat mastitis pada sapi perah Fries Holland penderita mastitis sub-klinis. Jurnal Indonesia Tropical Animal Science. 32(2): 76-79.

Owens, W.E., S.C. Nickerson, R.L. Boddie, G.M. Tomite and C.H. Ray. 2001. Prevalence of mastitis in dairy heifers and effectiveness. Journal Dairy Science. 84(4): 814-817.

Poeloengan, M. 2009. Aktivitas air perasan dan ekstrak etanol daun encok terhadap bakteri yang diisolasi dari sapi mastitis subklinis. Dalam: Seminar Nasional Teknologi Peternakan dan Veteriner 2009. Balai Besar Penelitian Veteriner. Bogor. Hal. 300-305.

Poutrel, B. and M. Ducelliez. 1978. Study of factors influencing the effectiveness of two treatments, penicillinstreptomycin and rifamycin, against experimentally induced staphylococcal mastitis in lactating cows. Station de Pathologie de la Reproduction, Centre de Recherches de Tours, 1. N R A. Nouzilly. France. 9(3): 471-487.

Primadani, A.H., Sarwiyono dan P. Surjowardojo. 2013. Pengaruh teat dipping menggunakan dekok daun kersen (Muntingia calabura L.) terhadap hasil uji reduktase dan uji berat jenis susu sapi FH laktasi. Jurnal Universitas Brawijaya. Malang. http://jurnal.ub.ac.id. (Diakses pada tanggal 19 Januari 2016).

Reugg, P.L. and D.J. Reinemann. 2002. Milk quality and mastitis test. Scientific Paper. University of Wisconsin. Madison.

Rismardiati, D.U. 1985. Preparat Penisilin dalam Pengobatan Mastitis Sapi Perah. 
Skripsi. Fakultas Kedokteran Hewan. Institut Pertanian Bogor. Bogor.

Schroeder, J.W. 2012. Mastitis Control Program: Mastitis Bovine and Milking Managenent. Exstention Dairy Specialist. North Dakota University Fargo. North Dakota.

Sevia, A., M. Taibi, A. Albenzioa and G. Musci. 1999. Effect of parity on milk yield, composition, somatic cell count, renneting parameters and bacteria counts of comisana ewes. Small Ruminant Research. 37(2000): 99-107.

Sharif, A., M. Umer and G. Muhammad. 2009. Mastitis control in dairy production. Journal of Agriculture and Social Sciences. 5(3): 102-105.

Soedono, A., R.F. Rosdiana dan B.S. Setiawan. 2003. Beternak Sapi Perah Secara Intensif. Agromedia Pustaka. Jakarta.

Standar Nasional Indonesia. 2011. Susu Segar. Bagian 1: Sapi. SNI 3141.1:2011. Badan Standarisasi Nasional. Republik Indonesia.

Sudarman, A. dan D. Diapari. 2012. Suplementasi Tepung Daun Sirih (Piper betle 1.) dalam Ransum Sapi Perah untuk Mencegah dan Mengobati Penyakit Mastitis Subklinis guna Meningkatkan Produksi Susu. Laporan Akhir Hibah Kompetitif Penelitian Strategis Nasional. Lembaga Penelitian dan Pengabdian Kepada Masyarakat. Institut Pertanian Bogor. Bogor.

Sudarwanto, M. dan E. Sudarnika. 2008. Hubungan antara $\mathrm{pH}$ susu dengan jumlah sel somatik sebagai parameter mastitis subklinik. Media Peternakan edisi Agustus 2008. Departemen Ilmu Penyakit Hewan dan Kesehatan Masyarakat Veteriner. Fakultas Kedokteran Hewan. Institut Pertanian Bogor. Bogor. 31(2): 107-113.

Sudarwanto, M., H. Latif dan M. Noordin. 2006. The relationship of the somatic cell counting to sub-clinical mastitis and to improve milk quality. Dalam: Proceedings of the 1st International American Anti-Vivisection Society Scientific Conference. Faculty of Veterinary Medicine, Bogor Agricultural University. Bogor. Hal. 78-82.

Sudhan, N. A. and N. Sharma. 2010. MastitisAn Important Production Disease of Dairy Animals. SMVS ‘ Dairy Year Book 2010. Jammu. pp. 72-88.

Supar dan T. Ariyanti. 2008. Kajian pengendalian mastitis subklinis pada sapi perah. Dalam: Prosiding Prospek Industri Sapi Perah Menuju Perdagangan Bebas 2020. Balai Penelitian dan Pengembangan Peternakan. Departemen Pertanian. Bogor. Hal. 360-366.

Suriyasathaporn, W. 2010. Milk quality and antimicrobial resistance against mastitis pathogen after changing from a conventional to an experimentally organic dairy farm. Asian-Australian Journal Animal Science. 23(5):659664.

Susanty, H. dan E. Nurdin. 2012. Efek pemberian temu putih (Curcuma zedoaria) terhadap kualitas susu sapi perah penderita mastitis subklinis. Jurnal Peternakan Indonesia. 14(2): 368-372.

Suwandi. 2003. Peran antibiotika dalam pengobatan ternak di kandang percobaan. Dalam: Prosiding Temu Teknis Fungsional Non Peneliti 2003. Pusat Penelitian dan Pengembangan Peternakan. Balai Penelitian Ternak. Bogor. Hal. 58-61.

Suwito, W. dan S. Indarjulianto. 2013. Staphylococcus aureus penyebab mastitis pada kambing peranakan etawah: epidemiologi, sifat klinis, patogenesis, diagnosis dan pengendalian. Wartazoa. 23(1): 1-7. 
Taylor, V. 2006. The warning signs of Mastitis: analyzing a combination of factors to decide when to treat. Ministry of Agriculture. Food and Rural

Affairs.

Ontario._http://www.omafra.gov.on.ca /english/livestock/dairy/facts/06049.htm. 20 Januari 2016.

Teddli, C. and F. Yu. 2007. Mixed methods sampling: a typology with examples. Journal of Mixed Methods Research. 1(1): 77-100.

Usmiati, S. dan Abubakar. 2009. Teknologi Pengolahan Susu. Balai Besar
Penelitian dan Pengembangan Pascapanen Pertanian. Bogor.

Utami, K.B., L.E. Radiati dan P. Surjowardojo. 2014. Kajian kualitas susu sapi perah PFH (studi kasus pada anggota Koperasi Agro Niaga di Kecamatan Jabung Kabupaten Malang). Jurnal- Jurnal Ilmu Peternakan. 24(2): 58-66.

Utomo, B. dan D.P. Miranti. 2010.Tampilan produksi susu sapi perah yang mendapat perbaikan manajemen pemeliharaan. Caraka Tani. 25(1): 2125 . 